\title{
AN INVESTIGATION OF THE ATMOSPHERIC SOURCES AND SINKS OF METHYL BROMIDE
}

\author{
Hanwant B. Singh
}

NASA Ames Research Center, Moffett Field, CA 94035

M. Kanakidou

Centre des Faibles Radioactivites, CNRS, F-91198 Gif sur Yvette Cedex, France

Abstract. Methyl Bromide ( $\mathrm{CH}_{3} \mathrm{Br}$ ) is a ubiquitous component of the atmosphere and has been implicated as an important player in the depletion of stratospheric ozone. Atmospheric $\mathrm{CH}_{3} \mathrm{Br}$ abundances, interhemispheric gradients, oceanic concentrations, man-made emissions, and removal processes have been analyzed and interpreted with the help of a simple box model and a 2-D global photochemical model. Its calculated atmospheric lifetime $(T)$ of 1.7-1.9 years, based on reaction with $\mathrm{OH}$ radicals, is consistent with a global source of $90-110 \mathrm{Gg}\left(10^{9} \mathrm{~g}\right) /$ year. Consequences of a much shorter lifetime of 1.2 years, due to possible deposition/hydrolysis losses, are also considered. Available data are used to estimate a $\mathrm{CH} 3 \mathrm{Br}$ source that is $35 \%(20-50 \%)$ man-made and $65 \%$ (80$50 \%$ ) natural. Oceans are substantially supersaturated and provide the most important natural source of $\approx 60(40-80)$ $\mathrm{Gg} /$ year. Within the oceans $200-300 \mathrm{Gg} /$ year of $\mathrm{CH}_{3} \mathrm{Br}$ may be produced. Indirect emissions from automobile exhaust and biomass burning can not be well quantified (1-10 Gg/year). A global trend of 0.1-0.2 ppt/year is predicted. Model results show significant vertical and seasonal variations in the atmospheric abundances and interhemispheric gradients of $\mathrm{CH}_{3} \mathrm{Br}$. Substantial uncertainties in calibrations, source estimates, and deposition processes are present.

\section{Introduction}

Methyl Bromide $\left(\mathrm{CH}_{3} \mathrm{Br}\right)$ is a ubiquitous component of the atmosphere and has been measured in polluted and remote environments. It has been used as a soil, grain and space fumigant for a number of decades and has significant man-made sources [CIS, 1992; CMA, 1992]. Limited data show that ocean waters are supersaturated with methyl halides and a large marine source of $\mathrm{CH}_{3} \mathrm{Br}$ is present [Lovelock, 1975; Singh et al., 1983]. Singh [1984] concluded that $\mathrm{CH}_{3} \mathrm{Br}$ is largely natural in origin with a small anthropogenic component. More recently, it has been proposed that it may be predominately of man-made origin [Penkett et al., 1985; WMO, 1989]. This distinction is important because bromine is nearly $40(30-120)$ times more effective than chlorine in stratospheric ozone destruction [Wofsy et al., 1975; Yung et al., 1980; McElroy et al., 1986; WMO, 1991; Mellouki et al., 1992]. It has been calculated that a $10 \%$ reduction in the emissions of $\mathrm{CH}_{3} \mathrm{Br}$ is equivalent to a 2 to 3 year acceleration in the phase out of CFCs under the Montreal protocol [WMO, 1991]. Proposals have been put forth to regulate and eliminate the use of $\mathrm{CH}_{3} \mathrm{Br}$. In light of these considerations a better understanding of its sources and sinks is warranted.

\section{Atmospheric and Oceanic Measurements of Methyl Bromide}

Atmospheric measurements. A number of studies in recent years have provided atmospheric measurements of $\mathrm{CH}_{3} \mathrm{Br}$. Data from some 15 cities in the U. S. show elevated concentrations $(130 \pm 110 \mathrm{ppt})$. Exceptionally high values (several $\mathrm{ppb})$ at some

\section{Copyright 1993 by the American Geophysical Union.}

Paper number 92GL02634

0094-8534/93/92GL-02634\$03.00
California sites have also been observed [Singh et al., 1977; 1992]. In remote marine atmospheres $\mathrm{CH}_{3} \mathrm{Br}$ mixing ratios of 5-30 ppt have typically been reported. Data collected from coastal Pacific sites do not show any discernible annual cycle or a long term trend [Singh et al., 1983, Cicerone et al., 1988]. In Table 1 we summarize the mean NH (northern hemisphere) and $\mathrm{SH}$ (southem hemisphere) surface air concentrations of $\mathrm{CH}_{3} \mathrm{Br}$ measured by several different investigators. No similar free tropospheric data were available in the published literature. A global background concentration of 10-20 ppt, with a preference for the 10-13 ppt range, is present. In addition a north/south concentration gradient is consistently seen. This $\mathrm{NH} / \mathrm{SH}$ ratio of 1.2-1.4 is largely independent of absolute calibrations and suggests a higher sources in the NH. Larger sinks (OH concentrations) in the SH compared to the NH have been suggested [Singh, 1977; Brenninkmeijer et al., 1992], and may also cause similar gradients. Recent models and methyl chloroform budget calculations do not support large hemispheric differences in the $\mathrm{OH}$ field [Prinn et al., 1992]. It is evident from Table 1 that measured $\mathrm{CH}_{3} \mathrm{Br}$ concentrations differ to within a factor of two. Although part of this could be due to the presence of local sources and seasonal effects, much of it is due to uncertainties in calibration standards.

Oceanic measurements. The only available sea water data are from the eastern Pacific [Singh et al., 1983]. These show that (i) sea water is significantly supersaturated (mean $250 \%$; median $180 \%$ ); (ii) mean sea water concentrations in the $\mathrm{NH}(1.1 \pm 0.8$ $\mathrm{ng} / \mathrm{L})$ and $\mathrm{SH}(1.2 \pm 0.7 \mathrm{ng} / \mathrm{L}$ ) are nearly equal and (iii) sea water concentrations of $\mathrm{CH}_{3} \mathrm{Br}$ and methyl chloride $\left(\mathrm{CH}_{3} \mathrm{Cl}\right)$ are significantly correlated $(R=0.85)$ pointing to a common oceanic source. In addition $\mathrm{CH}_{3} \mathrm{Cl}$, which is known to have a very small man-made sources, was nearly uniformly distributed in the two hemispheres. This implies that in the absence of man-made sources $\mathrm{CH}_{3} \mathrm{Br}$ would also be similarly distributed. These data can suggest, but not prove, that the marine sources of $\mathrm{CH}_{3} \mathrm{Br}$ in the two hemispheres may be more or less equal and the observed

Table 1: Mean methyl bromide mixing ratios (ppt) in the surface air of the northem and southern hemispheres

\begin{tabular}{|c|c|c|c|c|c|}
\hline $\mathrm{NH}$ & SH & NH/SH & Data Year & $\begin{array}{l}\text { Platform } \\
\text { (Region) }\end{array}$ & Ref. \\
\hline 26 & 20 & $1.30(1.15)^{*}$ & $\begin{array}{l}\text { 1981- } 1982 \\
\text { (December) }\end{array}$ & $\begin{array}{l}\text { Ship } \\
\text { (Pacific) }\end{array}$ & (1) \\
\hline 15 & 11 & $1.40(1.25)$ & $\begin{array}{l}\text { 1982-1983 } \\
\text { (November) }\end{array}$ & $\begin{array}{l}\text { Ship } \\
\text { (Atlantic) }\end{array}$ & (2) \\
\hline 11 & 10 & $1.15(1.10)$ & $\begin{array}{l}\text { 1985-1987 } \\
\text { (Ann. Avg.) }\end{array}$ & $\begin{array}{l}\text { Coastal } \\
\text { (Pacific) }\end{array}$ & (3) \\
\hline 11 & 8 & $1.35(1.25)$ & $\begin{array}{l}\text { 1983-1992 } \\
\text { (Ann. Avg.) }\end{array}$ & $\begin{array}{l}\text { Coastal } \\
\text { (Pacific) }\end{array}$ & (4) \\
\hline 10 & 8 & $1.20(1.15)$ & $\begin{array}{l}\text { 1988/1991 } \\
\text { (December) }\end{array}$ & $\begin{array}{l}\text { Coastal } \\
\text { (Pacific) }\end{array}$ & (5) \\
\hline 14 & - & - & $\begin{array}{c}\text { 1991/1992 } \\
\text { (April) }\end{array}$ & Aircraft & (6) \\
\hline
\end{tabular}

*Annual mean hemispheric ratio, obtained by correcting surface ratio with the 2-D model. (1) Singh et al. [1983], (2) Penkett et al. [1985], (3) Cicerone et al. [1988], (4) R. A. Rasmussen-private comm., (5) F.S. Rowland- private comm., (6) L. Heidt- private comm. 
$\mathrm{NH} / \mathrm{SH}$ gradients are largely due to man-made sources in the NH.

Mechanisms by which $\mathrm{CH}_{3} \mathrm{Br}$ (or other methyl halides) may be produced in sea water are not well known. Zafiriou [1975] has proposed that $\mathrm{Cl}^{-}$and $\mathrm{Br}$ ions in sea water may react with methyl iodide $\left(\mathrm{CH}_{3} \mathrm{I}\right)$, produced by marine algae, to rapidly (several days) form $\mathrm{CH}_{3} \mathrm{Br}$ and $\mathrm{CH}_{3} \mathrm{Cl}\left(\mathrm{CH}_{3} \mathrm{I}+\mathrm{Br}^{-} \rightarrow\right.$ $\mathrm{CH}_{3} \mathrm{Br} \mathrm{I}^{-}$). Singh et al. [1983] were unable to find any correlation between sea water concentrations of $\mathrm{CH}_{3} \mathrm{I}$ with those of $\mathrm{CH}_{3} \mathrm{Br}$ or $\mathrm{CH}_{3} \mathrm{Cl}$, suggesting that this was probably not a dominant mechanism. Another possibility [White, 1982] may be either direct emission from organisms or by reaction between dimethyl sulfonium and halide ions in sea water $\left[\left(\mathrm{CH}_{3}\right)_{2} \mathrm{~S}^{+}-\right.$ $\mathrm{R}+\mathrm{Br}^{-} \rightarrow \mathrm{CH}_{3} \mathrm{Br}+\mathrm{CH}_{3} \mathrm{SR}$ ].

\section{Sources of Methyl Bromide}

Man-made sources. Singh [1984] estimated that 15-20 $\mathrm{Gg} /$ /year of $\mathrm{CH} 3 \mathrm{Br}$ is released from man-made sources alone. Recently, the Methyl Bromide Industrial Panel, an industry group, has prepared a new inventory of $\mathrm{CH}_{3} \mathrm{Br}$ production, sales and use [CMA, 1992]. Table 2 shows the aggregated global sales of $\mathrm{CH}_{3} \mathrm{Br}$ from 1965-1990. The 1965 and 1975 sales are obtained from CIS [1992]. An average annual growth rate of about 5\% is indicated. An exponential function provides a best fit $(R=0.99)$ to these data [Sales $(\mathrm{Gg} /$ year $)=0.8646 \exp ($ 0.0477 (year-1900)) \}. Approximately $93 \%$ of the sales occur in the NH and $7 \%$ in the SH.

Nearly $95 \%$ of all $\mathrm{CH}_{3} \mathrm{Br}$ sold is used in various soil, grain and space fumigation applications with a very small fraction $(\approx 5 \%)$ finding use as a chemical intermediate. Fumigation usages involves pre-planting $(\approx 75 \%)$, post harvesting $(\approx 15 \%)$ and structural $(\approx 5 \%)$ applications. $\mathrm{CH}_{3} \mathrm{Br}$ is decomposed in soils at a rate of $5-10 \%$ /day via processes of hydrolysis and demethylation [Gentile et al., 1989]. The biggest use is preplanting fumigation and here the actual fraction emitted is dependent on soil variables such as organic carbon, moisture, $\mathrm{pH}$ etc. and the manner of application. Numerical models of soil vapor migration, that take into account current use practices and typical soil types, have been used to calculate that $42 \pm 10 \%$ (30$60 \%$ ) of the $\mathrm{CH}_{3} \mathrm{Br}$ applied may be ultimately released to the atmosphere [Reible, D., private comm., 1992]. In space and grain fumigation applications a higher fraction $(\approx 80 \%)$ is probably released to the atmosphere. The current best estimate, based on studies by the Methyl Bromide Global Coalition, is that approximately $50 \%$ of $\mathrm{CH}_{3} \mathrm{Br}$ sold is emitted to the atmosphere.

Indirect emissions of $\mathrm{CH}_{3} \mathrm{Br}$ are also possible. There are preliminary indications that exhaust from automobiles, especially burning leaded gasoline, may be a source [Harsch and Rasmussen, 1977j. This is consistent with the high $\mathrm{CH}_{3} \mathrm{Br}$ levels that have been reported in urban air. It is further possible that biomass burning, which is known to produce important quantities of $\mathrm{CH}_{3} \mathrm{Cl}$, may also be a source. No biomass burning data are available but, based on $\mathrm{Br} / \mathrm{Cl}$ availability $(\mathrm{Br} / \mathrm{Cl}<0.005)$, this source can be estimated to be quite small ( $<3 \mathrm{Gg} / \mathrm{year}$ ). It is possible that such indirect sources could add up to a global emission of $1-10 \mathrm{Gg} /$ year.

Table 2: Annual word-wide sales and emissions ( $\mathrm{Gg} ; 10^{9} \mathrm{~g}$ ) of man-made (MM) methyl bromide from 1965-1990

\begin{tabular}{lccccccccc}
\hline Year & 65 & 75 & 84 & 85 & 86 & 87 & 88 & 89 & 90 \\
\hline Sales* & 20 & 30 & 46 & 48 & 50 & 56 & 60 & 62 & 66 \\
Emissions* & 10 & 15 & 23 & 24 & 25 & 28 & 30 & 31 & 33 \\
\% MM* & 14 & 20 & 28 & 29 & 29 & 32 & 33 & 34 & 36 \\
\hline *Sales(Gg/year)=0.8646exp[0.0477(year-1900)];R=0.99; \\
Emissions=50\% of sales; Natural marine source $=60$ Gg/year.
\end{tabular}

Oceanic sources. Using the film model of Liss and Slater [1974] and based on the data collected in and over the eastern Pacific Ocean, Singh et al. [1983] calculated an average oceanic supersaturation of $180 \%$ (median ) to $250 \%$ (mean) corresponding to a flux of $65-90 \mathrm{ng} \mathrm{cm}^{-2}$ year-1. Extrapolated to global oceans, this flux corresponds to a marine source of nearly 220-300 Gg/year. More recent information permits \& reevaluation of these results. The first possible correction is due to disagreement in calibration standards. As can be seen from Table 1, all subsequent measurements are lower by a factor of about two. A second difficulty is in extrapolating the eastern Pacific data to global oceans. Productivity maps show that the sampled area is substantially (two to four times) more productive than the open Pacific Ocean [Koblentz-Mishke et al., 1970]. Another way to accomplish this extrapolation is to normalize $\mathrm{CH}_{3} \mathrm{Br}$ flux to that of $\mathrm{CH}_{3} \mathrm{Cl}$ which has been better studied and appear to have a common source with $\mathrm{CH}_{3} \mathrm{Br}$. $\mathrm{CH}_{3} \mathrm{Cl}$ flux for this region is roughly double the global average flux. Scaling by normalizing to either productivity or $\mathrm{CH}_{3} \mathrm{Cl}$, suggests that the mean global $\mathrm{CH}_{3} \mathrm{Br}$ flux is about half to one third that of the eastern Pacific Ocean. These considerations imply a global oceanic source of $40-80 \mathrm{Gg}$ /year. The analogy with $\mathrm{CH}_{3} \mathrm{Cl}$ also allows us to assume that this source is nearly equally distributed in the two hemispheres.

$\mathrm{CH}_{3} \mathrm{Br}$ hydrolyzes in neutral water at a rate of $2 \% /$ day at $22^{\circ} \mathrm{C}$ and $3 \% / d a y$ at $30^{\circ} \mathrm{C}$ [Mabe and Mill, 1978]. It may also be decomposed in sea water by reaction with $\mathrm{Cl}^{-}$ions at a comparable or faster rate [Elliot, 1985]. Assuming a removal rate of $4-6 \%$ /day within the mixed layer ( $\approx 70$ meters) of the world oceans the data of Singh et al. [1983], as interpreted above, can be used to calculate a $\mathrm{CH}_{3} \mathrm{Br}$ production of 200-300 $\mathrm{Gg} / \mathrm{year}$ within the oceans.

\section{Data Analysis and Discussion}

In this section we use available data to evaluate the lifetime and budget of $\mathrm{CH}_{3} \mathrm{Br}$. Data are first analyzed with the help of a 2-box model and further refined by using a global 2-D phorochemical model [Kanakidou et al., 1991].

Methyl bromide lifetime. The reaction with hydroxyl radical is thought to be the principal atmospheric removal mechanism for $\mathrm{CH} 3 \mathrm{Br}$. Recently Mellouki et al. [1992] have measured this $\mathrm{OH}$ rate constant $\left(\mathrm{kOH}=2.35 \times 10^{-12} \exp (-1300 / \mathrm{T})\right)$ and calculate a $\mathrm{CH}_{3} \mathrm{Br}$ lifetime $(\mathrm{T})$ of 1.7 years based on this process alone. The 2-D model used in this study calculates a $\mathrm{T}$ of 1.9 years and a methyl chloroform lifetime of 6.2 years in reasonable agreement with its budget estimates [Talukdar et al., 1992; Prinn et al., 1992]. Because CH3Br can hydrolyze as well as react with $\mathrm{Cl}^{-}$ions and organic carbon, its loss via deposition/hydrolysis is possible. If oceans were substantially undersaturated, the dissolution of $\mathrm{CH}_{3} \mathrm{Br}$ in the sea water followed by hydrolysis would provide an important sink with an atmospheric turn over rate of the order of 3 years. This corresponds to a uniform deposition velocity of $0.01 \mathrm{~cm} / \mathrm{s}$. No direct measurements of deposition have been made. Although Singh et al. [1983] found sea water supersaturation at all times, the possibility that parts of the oceans are under-saturated and are actual sinks can not be ruled out. Tropospheric photolysis and rainout/washout are calculated to be negligible sinks. Stratospheric loss can provide a turn over rate of about 30 years [WMO, 1991]. For subsequent calculations, we assume a $\mathrm{CH}_{3} \mathrm{Br}$ lifetime of 1.7-1.9 years. Consequences of a much shorter lifetime of 1.2 years, possibly resulting from deposition/hydrolysis losses, are also discussed.

Two-box model. As a start a 2-box model [Singh, 1977] is used to describe the atmospheric distribution of $\mathrm{CH}_{3} \mathrm{Br}$.

$$
\begin{aligned}
& \mathrm{dC}_{n} / \mathrm{dt}=\mathrm{F}_{\mathrm{n}}-\left(\mathrm{C}_{\mathrm{n}}-\mathrm{C}_{\mathrm{s}}\right) / \mathrm{t}_{\mathrm{e}}-\mathrm{C}_{\mathbf{n}} / \mathrm{T} \\
& \mathrm{dC}_{\mathrm{S}} / \mathrm{dt}=\mathrm{F}_{\mathrm{S}}+\left(\mathrm{C}_{\mathrm{n}}-\mathrm{C}_{\mathrm{S}}\right) / \mathrm{t}_{\mathrm{e}}-\mathrm{C}_{\mathrm{S}} / \mathrm{T} \\
& \mathrm{F}_{\mathrm{n}}=0.5 \mathrm{~N}_{\mathrm{O}}+(1-\mathrm{f}) \mathrm{m} \mathrm{ept} \\
& F_{s}=0.5 N_{0}+f m e p t
\end{aligned}
$$


Where $\mathrm{C}_{n}$ and $\mathrm{C}_{\mathrm{s}}$ are mean (annual averages) $\mathrm{CH}_{3} \mathrm{Br}$ atmospheric loadings in the $\mathrm{NH}$ and $\mathrm{SH}$, te is the mean interhemispheric exchange rate, $f$ is the fraction of the man-made source emitted in the $\mathrm{SH}$, and $\mathrm{p}$ is a measure of temporal growth rate. By analogy with $\mathrm{CH}_{3} \mathrm{Cl}$, the total source in each hemisphere $\left(F_{n}\right.$ and $\left.F_{S}\right)$ is assumed to be made of an equal natural $\left(0.5 \mathrm{~N}_{\mathrm{O}}\right)$ and a man-made component fit to an exponential function. A steady state solution to the above equations leads to the following result.

$\left(\mathrm{C}_{\mathrm{n}}-0.5 \mathrm{TN}_{0}\right) /\left(\mathrm{C}_{\mathrm{S}}-0.5 \mathrm{TN}_{0}\right)=\mathrm{te}_{\mathrm{e}}\left[\mathrm{p}+1 / \mathrm{te}_{\mathrm{e}}+(1-\mathrm{f}) / \mathrm{T}\right] \equiv \theta$

$\mathrm{TN}_{\mathrm{o}} /\left(\mathrm{C}_{\mathrm{n}}+\mathrm{C}_{\mathrm{s}}\right)=2\left(\theta-\mathrm{C}_{\mathrm{n}} / \mathrm{C}_{\mathrm{s}}\right) /\left[(\theta-1)\left(1+\mathrm{C}_{\mathrm{n}} / \mathrm{C}_{\mathrm{s}}\right)\right]$

Equation 4 is arranged to provide the fraction that is of natural origin. A te of 1.1-1.2 years, $T$ of 1.7-1.9 years, $p$ of 0.048 and $f$ of 0.07 represent typical mean values. If one assumes that the natural source does not exist $\left(\mathrm{N}_{0}=0\right)$ then a $\mathrm{C}_{\mathrm{n}} / \mathrm{C}_{\mathrm{S}}$ of 1.6-1.8 can be calculated from equation (3). (A ratio of 1.9 can be derived with a $T$ of 1.2 years). The 2-D model also confurms the large north-south gradients associated with an exclusive manmade source set to $150 \%$ of sales (Figure 1a-I and I'). Sensitivity studies with a much smaller source (set to $50 \%$ of sales) showed that this gradient was smaller by only about $10 \%$. This is significantly greater than the measured concentration ratios, corrected for season and altitude effects, of 1.1-1.25 (Table 1). This comparison supports the notion that significant sources of $\mathrm{CH}_{3} \mathrm{Br}$ in the $\mathrm{SH}$ (presumably natural ) must exist.

Using the mean $C_{n} / C_{s}$ value of 1.1-1.25 (Table 1), equations 3 and 4 can be used to calculate a natural (or man-made) fraction that best fits the observations. For a $T$ of $1.7-1.9$ years, an average man-made fraction of about $35 \%(20-50 \%)$ can be calculated. An assumed T of 1.2 years results in a calculated

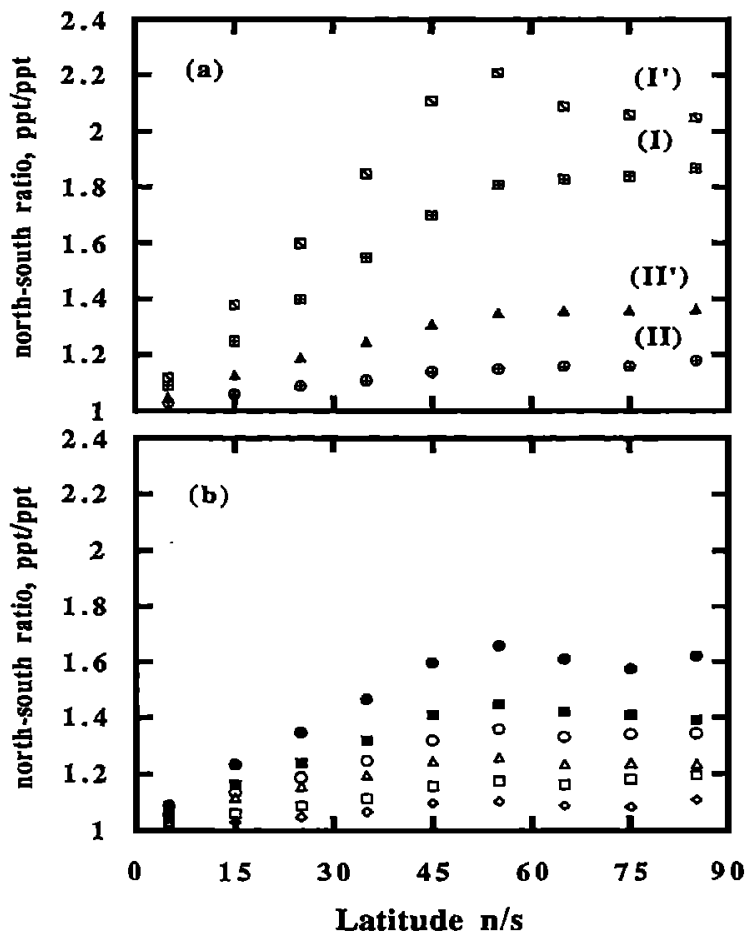

Fig. 1: Model calculated north-south ratios of $\mathrm{CH}_{3} \mathrm{Br}$ abundances. Open and solid symbols are for deposition velocity $\left(\mathrm{V}_{\mathrm{d}}\right.$ in $\left.\mathrm{cm} / \mathrm{s}\right)$ of $0.0(\mathrm{~T}=1.9$ years) and $0.0125(\mathrm{~T}=1.2$ years), respectively. (a) (I) shows annual and column averaged (0-10 $\mathrm{km})$ ratios with exclusive man-made source of $150 \%$ of sales, (I') is same as (I) but for surface level, (II) and (II) use emission source as described in Table 2; (b) surface ratios as a function of season, source same as in (II) and Symbols are Circles-March 30, Squares-June 30, Diamonds-September 30, Triangles-December 30.

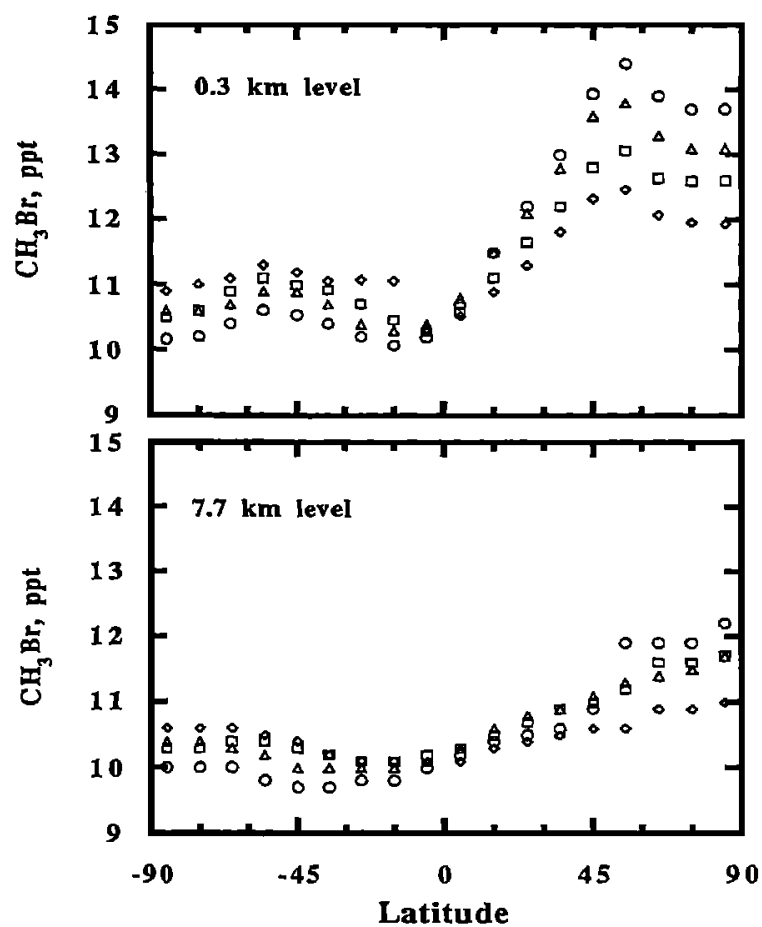

Fig. 2: Model calculated mixing ratios of $\mathrm{CH}_{3} \mathrm{Br}$ in the lower and upper troposphere for four seasons in 1985. Emission source from Table 2 and $V_{d}=0.0$. Symbols as in Fig. $1(b)$.

man-made fraction of $27 \%(20-35 \%)$. A global mean concentration of $12 \mathrm{ppt}$ corresponds to a total $\mathrm{CH}_{3} \mathrm{~B} \mathrm{r}$ atmospheric loading of $177 \mathrm{Gg}$ and a source of $93 \mathrm{Gg} /$ year ( $T=1.9$ years), 61 natural and 32 man-made. However, if the lifetime of $\mathrm{CH}_{3} \mathrm{Br}$ is as short as 1.2 year, then a much larger source of $147 \mathrm{Gg} /$ year, 107 natural and 40 man-made, is also not entirely outside the bound of possibilities.

2-D model calculations. The above 2-box model provides a preliminary picture of the source distribution of $\mathrm{CH}_{3} \mathrm{Br}$. A 2-D model of the global atmosphere [Kanakidou et al., 1991] is used to more accurately assess its global distribution and budget. This is especially important since the data are nearly all from the surface and the lifetime of $\mathrm{CH}_{3} \mathrm{Br}$ is short enough to result in seasonal and vertical gradients. This 2-D model produces an asymmetry in the $\mathrm{OH}$ field with $\mathrm{NH}$ values about $20 \%$ larger than SH. This has the net effect of under-predicting north-south ratios by about $5 \%$. Loss of $\mathrm{CH}_{3} \mathrm{Br}$ by mechanisms other than $\mathrm{OH}$ removal are poorly known but possible. Simulations were

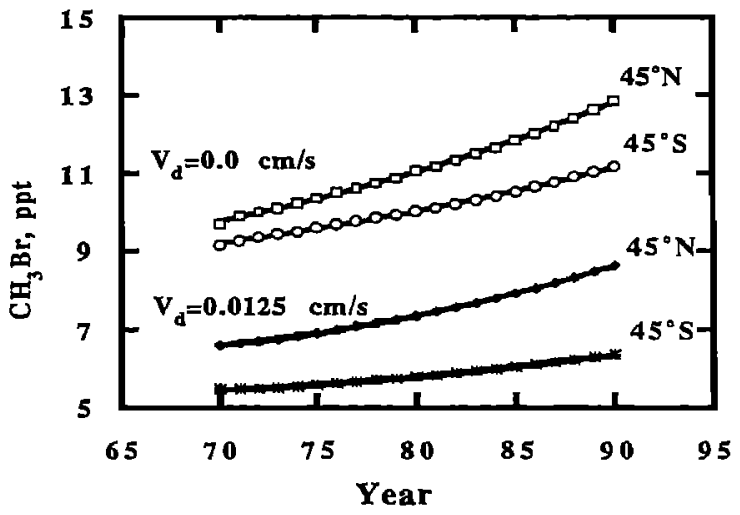

Fig. 3: Predicted atmospheric growth of $\mathrm{CH}_{3} \mathrm{Br}$ at $45^{\circ} \mathrm{N}$ and $45^{\circ} \mathrm{S}$ from 1970 to 1990 . Annual and column averaged (0-10 $\mathrm{km}$ ) mixing ratios. Emission source from Table 2. 
performed assuming no deposition $\left(\mathrm{V}_{\mathrm{d}}=0.0 \mathrm{~cm} / \mathrm{s}\right)$ and a deposition velocity of $0.0125 \mathrm{~cm} / \mathrm{s}$ over the oceans to simulate the hydrolysis loss rate. The global mean lifetime of $\mathrm{CH}_{3} \mathrm{Br}$ as calculated by this model is 1.9 years $\left(\mathrm{V}_{\mathrm{d}}=0.0 \mathrm{~cm} / \mathrm{s}\right)$ and 1.2 years $\left(\mathrm{V}_{\mathrm{d}}=0.0125 \mathrm{~cm} / \mathrm{s}\right)$.

Model runs were performed from 1965 to 1990 to study both the distribution and trends of $\mathrm{CH}_{3} \mathrm{Br}$ for the case of exclusive man-made sources and a combination of man-made and natural sources (Table 2). The man-made source of $\mathrm{CH}_{3} \mathrm{Br}$ was distributed by $10^{\circ}$ latitude belts based on the sales data [CMA, 1992]. This amounted to $93 \%$ emission in the $\mathrm{NH}$ and $7 \%$ in the SH. Nearly $80 \%$ of the global emissions occur within 30 $60^{\circ} \mathrm{N}$. An oceanic source of $60 \mathrm{Gg} /$ year distributed equally in both hemispheres was used. Figure 2 shows the 1985 atmospheric distribution of $\mathrm{CH}_{3} \mathrm{Br}$ as a function of latitude and height for four seasons and for the case of no deposition ( $T=1.9$ years). As expected, both seasonal and vertical gradients are present but high precision measurements are required to identify these. Simulations with an oceanic deposition rate of 0.0125 $\mathrm{cm} / \mathrm{s}$ ( $T=1.2$ years) reduced the predicted atmospheric concentrations by about $40 \%$ and increased the hemispheric ratios by about 15\% (Figure 1). Figures 1 and 2 clearly show that the north/south ratio is a strong function of altitude and season. In fact in a select season (e. g. NH winter) interhemispheric gradients could be created by the asymmetry in the removal processes alone. Unfortunately very little seasonal data are available and no seasonal cycles have been observed. The predicted north/south gradient of $\mathrm{CH}_{3} \mathrm{Br}$, based on the source described in Table 2 , is in reasonable agreement with observations.

Figure 3 shows the annual mean mixing ratios $(0$ to $10 \mathrm{~km}$ average) at $45^{\circ} \mathrm{N}$ and $45^{\circ} \mathrm{S}$ as a function of time with and without deposition. A quadratic fit accurately describes this trend. From 1970 to 1990 the growth rate increases from 0.10 to 0.22 $\mathrm{ppt} /$ year at $45^{\circ} \mathrm{N}$ and 0.08 to $0.13 \mathrm{ppt} /$ year at $45^{\circ} \mathrm{S}\left(\mathrm{V}_{\mathrm{d}}=0.0\right.$ $\mathrm{cm} / \mathrm{s})$. For the decade of the 80 's, a mean global trend of about 0.1-0.2 ppr/year is predicted by the 2-D model.

\section{Conclusions}

$\mathrm{CH}_{3} \mathrm{Br}$ is a globally distributed brominated organic chemical with substantial natural and man-made sources. A total global source of about $90 \mathrm{Gg} /$ year is likely to be present. Present data can be interpreted to suggest that two thirds of this source is natural and one third is man-made. An important natural source is in the oceans which appear to be substantially supersaturated. Mechanisms by which $\mathrm{CH}_{3} \mathrm{Br}$ (or other methyl halides) may be produced in sea water are not well known. The atmospheric lifetime of $\mathrm{CH}_{3} \mathrm{Br}$ is 1-2 years with $\mathrm{OH}$ radical and deposition processes as the likely controlling factors. Uncertainties in its atmospheric abundance, man-made and natural emissions, and physical removal processes are considerable. Future studies are crucially needed in all of these areas to better quantify the sources and sinks of $\mathrm{CH}_{3} \mathrm{Br}$.

Acknowledgments. This research was supported by the NASA Global Tropospheric Experiment. Special thanks are due to the MBGC and CMA for making available sales and production data. One of us (M. K.) expresses gratitude to the CEA, the CNRS and the MPI for support.

\section{References}

Brenninkmeijer, C. A., et al., An interhemispheric asymmetry in $\mathrm{OH}$ abundance inferred from measurements of atmosphere $14 \mathrm{CO}$, Nature, 356, 50-52, 1992.

CIS, Chemical Information Service, Chemical Economics Handbook, SRI International, Menlo Park, CA, 1992.

Cicerone, R. J., L. E. Heidt and W. H. Pollock, Measurements of atmospheric methyl bromide and bromoform, I. Geophys. Res., 93, 3745-3749, 1988.

CMA, Methyl bromide-annual production and sales for the years 1984-1990. The Methyl Bromide Industry Panel, Chemical Manufacturers Association, 1992.
Elliot, S., The chemistry of some atmospheric gases in the ocean, Ph. D. thesis, U. of California Irvine, 1985.

Gentile, I. A., L. Ferraris, and S. Crespi, The degradation of methyl bromide in some natural fresh waters, Pesti. Sci., 25, 261-272, 1989.

Harsch, D. E. and R. A. Rasmussen, Identification of methyl bromide in urban air, Anal. Lett., 10, 1041-1046, 1977.

Kanakidou, M., et al., A 2-D model study of ethane and propane oxidation in the troposphere, I. Geophys. Res., $26,15,395$. $15,413,1991$.

Koblentz-Mishke, O. J., V. V. Volkovinsky, and P. J. Kobanova, Plankton primary production of the world ocean, in Scientific Exploration of the South Pacific, ed. W. S. Wooster, National Academy of Sciences, Washington, D. C., 1970.

Lovelock, J. E., Natural halocarbons in air and in the sea, Nature, 256, 193-194, 1975.

Liss, P. S. and P. G. Slater, Flux of gases across the air sea interface, Nature, 247, 181-186, 1974.

McElroy, M. B., et al., Reductions of antarctic ozone due to synergistic interactions of chlorine and bromine, Nature, 321 759-762, 1986.

Mabey, W. R. and T. Mill, Critical review of hydrolysis of organic compounds in water under environmental conditions, I. Phys. Chem. Ref. Data 7, 383-415, 1978.

Mellouki, A., et al., Atmospheric lifetime and ozone depletion potentials of methyl bromide and dibromomethane, Geophys. Res. Lett., in press, 1992.

Penkett, S. A., et al., An interhemispheric comparison of the concentration of bromine compounds in the atmosphere, Nature, 318, 550-553, 1985.

Prinn, $R$. et al., Global average concentration and trend for hydroxyl radicals deduced from ALE/GAGE trichloroethane (methyl chloroform) data for 1978-1990, J. Geophys. Res. 97, 2445-2462, 1992.

Singh, H.B., Preliminary estimation of average tropospheric HO concentrations in the northern and southern hemispheres, Geophys. Res. Lett., 4, 453-456, 1977.

Singh, H.B., Halogenated methanes of natural origin, "Transaction of Environmental Impact of.Natural Emissions", Ed. V. Aneja, 193-206, 1984.

Singh, H.B., et al., The urban-nonurban relationships of halocarbons, $\mathrm{SF}_{6}, \mathrm{~N}_{2} \mathrm{O}$, and other atmospheric trace constituents, Atmos. Environ., 11, 819-828, 1977.

Singh, H.B., L.J. Salas, and R. Stiles, Methyl halides in and over the eastem Pacific $\left(35^{\circ} \mathrm{N}-35^{\circ} \mathrm{S}\right)$, I. Geophys. Res., 88 . 3684-3690, 1983.

Singh, H.B.et al., Measurement of volatile organic chemicals (VOC) at selected sites in california, Atmos. Environ., 26A, 2929-2946, 1992.

Talukdar R. K. et al., Kinetics of the OH Reaction with Methyl chloroform and its atmospheric implications, Science, 257, 227-230, 1992.

White, R. H., Analysis of dimethyl sulfonium compounds in marine algae, J. Mar. Res., 40, 529-536, 1982.

WMO, Scientific assessment of stratospheric ozone: 1989 , World Meteorological Organization, Report NO. 20, 1989.

WMO, Scientific assessment of ozone depletion: 1991, World Meteorological Organization, Report NO. 25, 1991.

Wofsy, S. C., M. B. McElroy, and Y. L. Yung, The chemistry of atmospheric bromine, Geophys. Res. Lett., 2 , 215-218, 1975.

Yung, Y. L., et al., Atmospheric bromine and ozone perturbations in the lower stratosphere, J.Atmos. Sci, 37 , 339-353, 1980.

Zafiriou, Reaction of methyl halides with sea water and marine aerosols, J. Mar. Res., 33, 75-81, 1975.

M. Kanakidou, Centre des Faibles Radioactivites, CNRS, F91198 Gif sur Yvette Cedex, France.

H. Singh, NASA Ames Research Center, Mail Stop 245-5, Moffett Field, CA 94035.

(Received: September 10, 1992; October 26, 1992) 